\title{
Pembaharuan hukum Islam dan problem otentisitas agama
}

\author{
Ahmad Khoirul Fata \\ Fak Ushuluddin \& Dakwah, IAIN Sultan Amai Gorontalo \\ email:cakfata@gmail.com,
}

Islam is a universal religion. Its validity beyond the boundaries of space and time, have challenges while confronted to modernity. New issues emerged make legal problems that must be faced by Islam, in this case fiqh, are becoming increasingly complex and require answers that are not easy. Many attempts were made contemporary muslim intellectual response to the challenge. In general, the effort was focused on two of epistemology: contextual interpretation and emphasis on the principle of maslahah. Practically, both the offer did generate a lot of laws in accordance with the present conditions. But apparently, both contain serious problems if not addressed promptly can undermine the foundations of religion that threatens the authenticity of Islam as a religion of revelation.

Islam sebagai agama universal yang keberlakuannya melampaui batasan ruang dan waktu menghadapi tantangan berat saat berhadapan dengan modernitas. Berbagai persoalan baru yang muncul membuat problematika hukum yang harus dihadapi Islam, dalam hal ini fikih, menjadi semakin kompleks dan membutuhkan jawaban yang tidak mudah. Banyak upaya dilakukan intelektual Islam kontemporer sebagai jawaban atas tantangan itu. Secara umum upaya itu berpusat pada dua epistemologi: penafsiran kontekstual dan penekanan pada asas maslahah. Dalam praktiknya, kedua tawaran tersebut memang menghasilkan banyak produk hukum yang sesuai dengan kondisi kekinian. Namun ternyata keduanya mengandung problem serius yang jika tidak segera dibenahi dapat menggerogoti sendi-sendi agama sehingga mengancam otentisitas Islam sebagai agama wahyu.

Keywords: Renewal; contextual; mașlạ̣ah

\section{Pendahuluan}

Agama hadir di dunia berfungsi sebagai petunjuk dan pedoman hidup bagi manusia. Keberadaan agama diyakini mampu menyelamatkan umat manusia dari bahaya kehidupan akibat perilaku dan kesalahan dirinya. Dapat diibaratkan, agama merupakan peta kehidupan 
yang dengannya manusia dapat berjalan ke jalan yang benar untuk mencapai tujuan hidupnya.

Islam sebagai agama terakhir dari rangkaian agama-agama wahyu hadir sebagai jalan hidup yang benar bagi seluruh umat manusia, semenjak kehadiran Rasulullah Muhammad Saw hingga akhir zaman. Posisi inilah yang kemudian menjadikan Islam selalu berlaku dan sesuai dengan kondisi zamannya (șalih li kulli zaman wa makean). Dengan keabadian inilah Islam menjadi istimewa dan unik. Dalam banyak hal kaum muslim meyakini apa yang mereka lakukan saat ini adalah

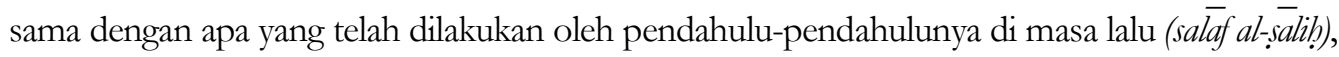
hanya pada aspek-aspek artifisial terdapat perbedaan. Maka tidak mengherankan jika sejarah Islam merupakan sejarah yang berputar dan berporos pada teks-teks pendahulunya itu.

Dalam putaran sejarah itu fikih menempati posisi istimewa mengingat fungsinya sebagai seperangkat pedoman yang bersifat praktis bagi kehidupan keseharian umat muslim; pribadi, keluarga, bermasyarakat, bahkan bernegara. Namun, modernitas yang menyapa dunia Islam sejak beberapa abad lalu membawa tantangan yang cukup berat bagi fikih. Perkembangan teknologi, industri, transportasi dan komunikasi membawa efek perubahan signifikan dalam kehidupan budaya, ekonomi, sosial, dan politik masyarakat muslim. Saat menghadapi perubahan-perubahan itu umat muslim berupaya mencari pegangan hidup kepada agama, dan fikih pun diharap menjadi institusi paling awal dalam pencarian itu. Sayangnya, banyak persoalan hidup yang hadir di zaman modern saat ini berbeda jauh dengan yang ada dalam teks-teks fikih klasik sehingga seringkali jawaban yang diberikan pun tidak aplikatif dan kompatibel dengan kehidupan kekinian. Akibatnya, perlahan-lahan fikih kehilangan elan vitalnya sebagai pepdoman praktis bagi kehidupan masyarakat muslim.

Di titik inilah banyak pihak yang berupaya melakukan upaya-upaya tertentu agar fikih bisa aplikatif dan kompatibel dengan kehidupan modern. Dalam pembacaannya atas tokohtokoh pemikir muslim kontemporer tentang pembaharuan hukum Islam (fikih) itu, Asni menyimpulkan setidaknya ada dua epistemologi yang saat ini berkembang, yaitu kontekstualisasi ajaran Islam dan penekanan pada aspek kemaslahatan (Asni, 2012: 153). Tulisan ini mencoba mengelaborasi gagasan pembaharuan itu dengan memberikan beberapa catatan kritis atas kedua epistemologi yang digunakannya. Sebagai langkah awal tulisan ini akan membahas beberapa istilah yang sering dipakai dalam kajian fikih (hukum Islam), baru kemudian mengkaji secara kritis gagasan pembaharuan fikih Islam kontemporer. 


\section{Fikih dan syariat}

Dalam praktik keseharian seringkali istilah fikih dan syariat dipersamakan atau dipahami sebagai dua hal yang memiliki pengertian yang sama. Padahal kedua istilah tersebut memiliki perbedaan yang cukup penting. Menurut Nur A Fadhil Lubis (Lubis, 2012: 3), terminologi syariah secara spesifik disebutkan hanya sekali dalam al-Qur'an, yaitu dalam QS al-Jatsiyah ayat 18 yang mengandungi dua makna: hukum dan ajaran-ajaran tentang keyakinan (aqidah). Menurut Guru Besar Hukum Islam Universitas Indonesia Muhammad Daud Ali, seperti yang dikutip Pradana Boy ZTF (Boy ZTF, 2012: 11), syariah adalah dasar norma legal yang ditentukan oleh Allah yang harus diturunkan ke dalam bentuk hukum yang spesifik. Di aspek ini fikih memainkan perannya dalam mendetailkan prinsip-prinsip universal itu ke dalam hukum substantif atau positif. Maka fikih bersifat spesifik, instrumental, terbagibagi dan dapat berubah.

Jika ditilik secara literal fikih (fiqh) bermakna "pemahaman" dan "ketajaman". Di aspek ini fikih sinonim dengan fahm, meskipun fikih seringkali bernuansa pemahaman yang lebih dalam (fahm al-daqiq). Pada awalnya kata ini digunakan mencakup berbagai macam pemahaman termasuk bidang teologi dan isu-isu sekular. Namun di kemudian hari istilah ini digunakan hanya pada pemahaman tentang hukum (Lubis, 2012: 3). Sedangkan secara istilah fikih adalah "Pengetahuan tentang hukum agama yang dihasilkan dari ijtihad" (Muzammil, 2012: 334).

Fikih ada tiga macam. Pertama, Qur'anic Fiqh, fikih yang telah disebutkan secara jelas dalam kitab suci al-Qur'an. Kedua, Nabawi Fiqh, fikih yang secara jelas terekspresikan dalam tradisi kenabian. Ketiga, Ijtihadi Figh, hukum-hukum yang diderivasikan melalui penalaran manusia. Literatur tentang fikh lebih banyak mengandungi kategori yang ketiga ini.

Produk dari fikih setidaknya ada lima bentuk; fatwa, pendapat hukum yang dinyatakan oleh beberapa ahli hukum, baik secara kolektif atau individu, sebagai jawaban atas pertanyaan dari masyarakat; qada, keputusan legal yang secara resmi dihasilkan oleh hakim di persidangan; qanun, aturan-aturan legal tentang perilaku bersama bagi daerah tertentu yang diputuskan oleh lembaga pembuat undang-undang; siyasah shar'iyyah, suatu aturan yang dibuat oleh penguasa untuk membantu implementasi aturan-aturan syariah; dan terakhir adalah qawl, suatu pendapat yang diungkapkan oleh beberapa ahli fikih (faqib) atau sekelompok ahli fikih (fuqaha'). 
Hukum Islam kategori syariah dihasilkan dari dalil qat ${ }^{\circ}$, sedangkan fikih dihasilkan dari dalil zanni. Qat'i artinya tegas sesuai dengan yang dikehendaki wahyu. Karena itu, hukum yang dihasilkan dari dalil qạt’i tidak memerlukan ijtihad. Berdasarkan hal tersebut, lahir prinsip di kalangan mayoritas ulama' ushul fikih bahwa tidak ada ijtihad dalam menghadapi nas. Adapun zanni adalah dugaan kuat seorang mujtahid. Syariah kebenarannya bersifat absolut, karena itu ia tidak menerima perubahan dan tetap berlaku universal di sepanjang zaman dan tempat. Sedangkan kebenaran fikih bersifat relatif yang dalam penerapannya, harus mengikuti situasi dan kondisi.

Dalam perjalanan sejarah awalnya, fikih merupakan kekuatan yang dinamis dan kreatif. Hal ini dapat dilihat dari munculnya sejumlah mazhab fikih di berbagai belahan daerah Islam dengan coraknya yang khas. Dinamika itu setidaknya didorong oleh empat faktor: Pertama, dorongan keagamaan Islam sebagai sumber norma dan nilai normatif yang mengatur seluruh aspek kehidupan muslim. Maka kebutuhan untuk mengintegrasikan nilai-nilai ke dalam kehidupan muslim selalu meuncul ke permukaan. Hukum Islam selalu dituntut untuk mampu memberikan pemecahan terhadap problem-problem baru yang dihadapi masyarakat. Dorongan perubahan itu selalu ada dalam kehidupan umat Islam dalam bentuk ijtihad. Kedua, meluasnya daerah kekuasaan umat Islam, khususnya di masa Umar bin Khattab dan Dinasti Bani Umayyah, melahirkan problem-problem hukum baru yang harus ditangani dengan segera. Dari sinilah muncul suatu kelas spesialis dalam hukum Islam di mana kaum muslim memperoleh bimbingan keagamaan untuk kehidupannya sehari-hari. Ketiga, independensi para spesialis hukum Islam itu dari kekuasaan politik. Keempat, sifat hukum Islam itu sendiri yang fleksibel sehingga mampu mengatasi ruang waktu. Fleksibilitas itu dapat dilihat dari lima prinsip dalam hukum Islam: ijma', qiyass, maslahah mursalah, al-urf, dan perubahan hukum dengan perubahan masa (Adnan Amal, 1996: 33-35).

\section{Tantangan modernitas}

Sayangnya fikih mengalami kemandegan dengan perkembangan taklid pasca runtuhnya Baghdad pada tahun 1258 sebagai respons atas timbulnya perpecahan politik Islam secara lebih besar. Kekhawatiran perpecahan yang lebih besar mendorong para intelektual muslim untuk menyeragamkan kehidupan sosial umat Islam dengan melarang berbagai jenis 
pembaruan yang substansial dalam hukum Islam.

Namun demikian, Taufiq Adnan Amal melihat benih-benih taklid sesungguhnya sudah tersemai sejak pertengahan abad ke $3 \mathrm{H} / 9 \mathrm{M}$ dengan kemunculan gagasan bahwa hanya ulama-ulama besar masa lampaulah yang berhak melakukan ijtihad. Pada abad ke $4 \mathrm{H}$ tercapai titik kritis di mana para fuqaha dari berbagai mazhab Sunni memandang bahwa seluruh permasalahan yang esensial telah dibahas secara tuntas. Konsesus diam-diam ini secara gradual memapankan klaim bahwa mulai saat itu tidak seorang pun yang memiliki kualifikasi melakukan ijtihad mutlak dan bahwa di masa mendatang seluruha aktivitas harus dibatasi hanya pada penjelasan, aplikasi, dan penafsiran doktrin yang telah dirumuskan.

Meski gerakan pembaharuan telah dimulai oleh Ibn Taymiyah (1263-1328) dan muridnya Ibnu Qayyim, kemudian pada penghujung abad $18 \mathrm{M}$ dilanjutkan Muhammad bin Abd alWahhab di Arabia dan Syah Wali Allah di India serta para pembaharu lainnya di abad-abad selanjutnya (Ibid: 37), namun para pembaharu muslim tampak kelimpungan menghadapi serbuan gagasan-gagasan, budaya, dan perkembangan teknologi dari Barat melalui kolonialisme.

Sebagai contoh pada awal abad ke-19, ahli-ahli hukum Islam di kerajaan Turki Utsmani kebingungan melihat hal-hal baru yang terdapat di kalangan umat Islam. Suatu permasalahan akan langsung dijawab haram bila ternyata tidak didapati dalam buku-buku klasik mazhab Hanafi. Dalam kasus percakapan lewat pesawat telepon yang baru-baru masuk ke wilayah Turki Utsmani saat itu, para ulama menfatwakan "haram" karena hal itu tidak tedapat dalam buku-buku fikih klasik (Zein, 1995: 287).

Kolonialisasi Barat atas dunia Islam telah melahirkan sejumlah perubahan radikal dalam tubuh umat Islam. Mentalitas sebagai bangsa terjajah membuat dunia Islam menjadikan Barat sebagai panutan dalam segala aspek kehidupan. Akibatnya, struktur sosial, ekonomi, politik dan budaya masyarakat muslim berubah secara drastis. Masyarakat terjajah yang sekian lama telah menganut sistemnya yang khas kini secara cepat berubah mengikuti gerak perubahan dari bangsa-bangsa penjajahnya. Masyarakat muslim melangkah mengikuti arus industrialisasi, mekanisasi, modernisasi, dan globalisasi. Arus itu pun membawa mereka ke dalam dunia baru yang diciptakan Barat dengan berbagai macam ide, gagasan, pemikiran, dan tradisi yang terasa asing bagi mereka. 
Perubahan radikal inilah yang menjadi tantangan tersendiri bagi sarjana-sarjana muslim, khususnya sarjana hukum Islam (fuqaha') yang memiliki tugas memberikan panduan praktis bagi masyarakat muslim. Dalam konteks masyarakat muslim era Turki Utsmani abad ke 19 M, tantangan tersebut setidaknya melahirkan tiga kelompok:

Pertama, kelompok yang ingin mempertahankan fikih dalam bentuk keadaannya, tanpa membedakan apakah hukum itu berupa ketegasan wahyu atau berupa ijtihad. Bagi mereka kemunduran umat Islam disebabkan oleh inkonsistensi dengan ajaran-ajaran hukum Islam. Umat Islam hendaknya secara ketat berpegang pada produk masa silam, baik di bidang ibadah maupun muamalah. Para ulama janganlah berijtihad karena mereka tidak se-alim dan sepandai ulama-ulama mujtahid terdahulu.

Kedua, kelompok yang berpendapat berpegang pada hasil ijtihad masa lalu dalam bentuk seadanya tidak cukup untuk memecahkan masalah kekinian yang begitu kompleks. Mereka mencoba membedakan antara ajaran-ajaran yang bersifat absolut dan hasil ijtihad yang bersifat relatif kebenarannya. Mereka mencoba menafsirkan ulang dan menyesuaikan hukum Islam hasil ijtihad ulama masa lalu dengan kondisi kekinian, bukan ajaran yang murni dan tegas dinyatakan oleh wahyu.

Ketiga, kelompok yang apatis dengan gagasan kelompok kedua. Bagi mereka permasalahan yang serba kompleks di masa kini tidak akan terpecahkan oleh norma-norma agama dan ajaran hukum Islam. Pembaharuan fikih seperti yang dimaksud golongan kedua mereka yakini tidak akan banyak menghasilkan perubahan yang berarti. Di titik ini mereka mengkampanyekan bahwa hukum Islam tidak siap pakai dan tidak bisa lagi diandalkan untuk memecahkan permasalahan di abad modern ini (Ibid: 288-289).

Secara umum, dunia Islam mengalami pergolakan luar biasa dalam pergesekannya dengan modernitas. Berbagai gagasan pembaharuan muncul berseliweran mencoba memberikan tawaran solusi bagi problem-problem fikih modernitas tersebut. Beberapa pemikir muslim kontemporer yang ambil bagian di antaranya Fazlur Rahman, Asghar Ali Enggineer, dan Muhammad Syahrur. Tidak lupa beberapa pemikir muslim Indonesia juga ambil bagian: Hazairin, Munawir Sjadzali, Ali Yafie, Amir Syarifuddin, dan lainnya. Menurut Asni, gagasan para pemikir itu secara umum menekankan pada dua hal: penafsiran kontekstual dan pertimbangan kemaslahatan (Asni, 2012: 153). 


\section{Tafsir kontekstual}

Urgensi penafsiran kontekstual menjadi perhatian Fazlur Rahman yang menitikberatkan analisisnya pada pendekatan sejarah sosial dengan teori gerak ganda. Rahman berulangkali memberi penekanan yang tegas terhadap pentingnya pemahaman kondisi aktual masyarakat Arab pra-Islam dan masa Nabi Saw dalam rangka menafsirkan pernyataan-pernyataan legal dan sosio-ekonomik al-Qur'an. Pendekatan historis ini bahkan dipandangnya sebagai satu-satunya cara yang dapat diterima dan dapat berlaku adil kepada tuntutan intelektual ataupun integritas moral. Selain itu Rahman juga mengupayakan pemahaman atas tujuantujuan al-Qur'an dan menerapkannya ke dalam konteks kekinian yang kongkret (Adnan Amal, 1996: 189-190).

Gagasan tersebut kemudian dirumuskannya dalam sebuah metodologi yang terbangun dari tiga langkah: a). Pendekatan historis untuk menemukan makna teks al-Qur'an dalam bentangan karir dan perjuangan Nabi saw. b). pembedaan antara ketetapan legal dengan sasaran dan tujuan al-Qur'an. c). pemahaman dan penetapan sasaran al-Qur'an dengan memperhatikan secara sepenuhnya latar sosiologisnya (Ibid; 192).

Dalam tafsir kontekstual, digunakan metode sosio-historis untuk memahami suatu kepercayaan, ajaran atau kejadian dengan melihatnya sebagai suatu kenyataan yang mempunyai kesatuan mutlak dengan waktu, tempat, kebudayaan, golongan dan lingkungan tempat kepercayaan, ajaran dan kejadian itu muncul. Dalam konteks ajaran-ajaran Islam, metode sosio-historis merupakan abstraksi dari teori asbāb nuzūl dan asbāb wurüd; tidak hanya menelusuri peristiwa yang menjadi latar belakang atau sebab turunnya sebuah ayat atau hadis, tetapi dalam skala lebih besar berusaha menelaah kondisi sosial budaya bangsa Arab saat diturunkannya al-Qur'an (Asni, 2012: 166).

Selain Rahman, gagasan kontekstualisasi juga disuarakan Munawir Sjadzali dengan mengusung gagasan reaktualisasi ajaran Islam. Reaktualisasi Sjadzali didasari oleh kenyataan sikap mendua masyarakat muslim atas pelaksanaan ajaran-ajaran Islam. Sjadzali memberikan dua contoh sikap mendua itu: pertama, dalam kasus bunga bank di mana banyak masyarakat muslim meyakininya sebagai riba yang diharamkan agama. Namun dalam kenyataan seharihari mereka banyak yang menikmati bunga bank dan bertransaksi dengan perbankan. Kedua, berkaitan dengan pembagian harta warisan, al-Qur'an secara tegas menyatakan bahwa anak 
laki-laki mendapatkan bagian dua kali lebih besar dari anak perempuan. Namun pada praktiknya ketentuan tersebut banyak ditinggalkan oleh masyarakat muslim, termasuk mereka yang selama ini dikenal sebagai tokoh agama (Nafis, 1995: 87-90).

Ada beberapa dasar argumentasi urgensi reaktualisasi menurut Sjadzali, yaitu teori nashakh, yaitu pergeseran atau bahkan pembatalan terhadap hukum-hukum atau petunjuk yang telah diberikan dalam ayat-ayat yang diterima Nabi saw pada waktu-waktu sebelumnya. Selain itu juga pada teori adanya ruang lebar untuk penalaran intelektual dalam hukum muamalah dengan mengedepankan kemaslahatan masyarakat, dan perubahan waktu, tempat, situasi, tujuan dan adat istiadat (Asni, 2012:137).

Aplikasi teori Rahman bisa dicontohkan dalam kasus poligami. Menurutnya, kebolehan seorang laki-laki menikahi lebih dari seorang istri sebagaimana yang termaktub dalam QS al-Nisa' ayat 3 seharusnya diposisikan setelah syarat keadilan dalam poligami karena tema sentral al-Qur'an adalah keharusan menegakkan keadilan. Hal itu karena pesan inti al-Qur'an sebenarnya tidak menganjurkan poligami. Al-Qur'an justru memerintahkan monogami. Itulah ideal moral yang hendak dituju al-Qur'an. Al-Qur'an menerima ketentuan hukum untuk beristri lebih dari satu itu karena ketidakmungkinan menghapus praktik poligami seketika itu juga mengingat praktik poligami telah dikenal jauh sebelum Islam datang dan telah mentradisi di kalangan masyarakat Arab (Ibid: 156-157).

Sedangkan Sjadzali memberikan contoh aplikasi gagasannya pada kasus perbandingan bagian warisan anak laki-laki dengan anak perempuan. Terhadap QS al-Nisa' ayat 11 yang secara jelas menyebutkan bagian anak laki-laki 2 kali lebih banyak dari bagian anak perempuan, Sjadzali secar tegas mengenyampingkan makna harfiah ayat tersebut. Baginya, adanya nilai kemaslahatan dan adat atau nilai baru yang muncul memerlukan upaya reaktualisasi dengan pembagian waris 1:1 di antara anak laki-laki dan perempuan.

\section{Asas kemaslahatan}

Selain penafsiran kontekstual, pembaharuan hukum Islam juga didasarkan pada pertimbangan kemaslahatan. Hal itu terlihat dari gagasan reaktualisasi Sjadzali yang mencoba memberi bagian warisan sama antara anak laki-laki dengan anak perempuan. Selain mempertimbangkan aspek perubahan situasi dan kondisi kekian, upaya tersebut mengacu pada prinsip kemaslahatan 
dalam rangka mewujudkan keadilan bersama (Ibid; 162-163).

Terkait dengan ini Sjadzali meminjam teori kemaslahatan dari Abd al-Karim ibn Sa’id alThufi (w $716 \mathrm{H})$ yang lebih mengutamakan asas mașlạah atas naṣ dan ijma. Pandangan ini bertitik tolak dari maqāsid al-shari ${ }^{\bar{a}}$ h yang menegaskan bahwa hukum Islam itu disyariatkan untuk mewujudkan dan melindungi kemaslahatan umat manusia. Argumen al-Thufi dibangun di atas empat dasar (Hosen, 1995: 254-255):

Pertama, bahwa akal semata tanpa melalui wahyu dapat mengetahui kebaikan dan keburukan. Akan tetapi kemandirian akal itu dibatasinya dalam hal muamalah dan adat istiadat. Ia melepaskan ketergantungan pada petunjuk nas baik dan buruk pada dua bidang itu.

Kedua, bahwa mașlaḩah itu merupakan dalil syar'i mandiri yang ke-ḅujah-annya tidak tergantung pada "kesaksian" atau konfirmasi nas, tetapi hanya bergantung pada akal semata. Ketiga, bahwa mașlạ̣ah dijadikan sebagai dalil syar'i hanya pada bidang muamalah dan adat istiadat, sedangkan dalam bidang ibadat dan muqaddarat tidak dapat dijadikan dalil. Dalam dua hal ini nas dan ijma' yang harus diikuti.

Keempat, maslaḥah merupakan huijah saat tidak terdapat nas dan ijma', dan harus didahulukan saat terdapat pertentangan antara keduanya. Namun al-Thufi memberi catatan, pengutamaan maslahah atas nas dan ijma' dilakukan dengan jalan bayān (penjelasan) dan takbsīis (pengkhususan), bukan dengan mengabaikan atau meninggalkan nas sama sekali.

\section{Otentisitas agama}

Pembaharuan menjadi hal penting bagi eksistensi hukum Islam di era modern. Kemampuan 'bergaul' dengan baik dengan realitas yang berubah menjadi modal utama agar ajaran Islam tetap menjadi sălị̣ li kulli zamān wa makān. Untuk menghadapi perubahan yang terjadi, Islam telah menyiapkan diri dengan konsep ijtihäd. Ijtihad secara bahasa berarti mencurahkan segala kemampuan dan mengerahkan kesungguhan. Dalam terminologi ushul fikih ijtihad dimaknai sebagai mencurahkan segala kemampuan dalam mencari pengetahuan tentang hukum-hukum dari dalil-dalil syara'. Dalam ungkapan lain ijtihad merupakan usaha sungguh-sunguh untuk mencapai suatu putusan syara' (hukum Islam) tentang kasus yang penyelesaiannya belum tertera dalam al-Qur'an dan sunah Rasulullah Saw (Asni, 2012: 47-48). 
Dalam kajian pemikiran Islam term ijtihad sering disamakan dengan pembaharuan (tajdid atau reformasi), yaitu proses pengembangan terhadap pemikiran-pemikiran yang telah ada karena adanya perkembangan yang terjadi di masyarakat. Sementara dalam konteks hukum Islam pembaharuan dilakukan melalui proses tertentu dengan penuh kesungguhan oleh pihak-pihak yang memiliki kompetensi dan otoritas dalam pengembangan hukum Islam melalui cara-cara yang telah ditentukan berdasarkan kaidah-kaidah istinbäthukum, agar hukum Islam dapat disesuaikan dengan perkembangan zaman (Ibid: 42).

Di masa lalu ijtihad yang dilakukan fukaha berkembang dalam kerangka ushul fiqh dengan

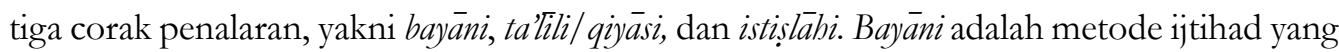
terkait dengan elaborasi makna lafadz, yakni berusaha menjelaskan makna-makna nas yang masih memerlukan kejelasan (mujmäl), baik karena makna lafadznya belum jelas maupun karena lafadz tersebut mengandung makna ganda dan persoalan-persoalan lafadz lainnya seperti mushtarak atau 'àm serta analisis macam-macam dilälah-nya (Ibid; 124).

Penalaran ta'ilili adalah upaya penggalian hukum yang bertumpu pada penentuan illahillah hukum yang terdapat dalam suatu naṣ. Upaya ini dilakukan untuk menemukan hukum terhadap permasalahan atas suatu kejadian yang tidak ditemukan dalilnya secara tersurat dalam nas baik qat’i atau zanni. Yang termasuk dalam corak penalaran ini adalah metode qiyās dan istiḥsan. Sedangkan istịlāḥi adalah upaya penggalian hukum yang bertumpu pada prinsip-prinsip kemaslahatan yang disimpulkan dari al-Qur'an dan sunah. Penalaran ini tampak pada beberapa metode ijtihad antara lain al-maslạ̣ah mursalah dan sadd al-darā'i. Menurut Asni penalaran inilah yang paling berpeluang dijadikan dasar lahirnya pemikiran-pemikiran baru dalam hukum Islam mengingat tidak semua masalah yang dihadapi manusia memiliki pautan langsung dengan nas al-Qur'an maupun hadits (Ibid: 126-127).

Tampaknya epistemologi tafsir kontekstual dan penekanan pada asas kemaslahatan yang banyak digunakan para pemikir muslim kontemporer menemukan ruangnya dalam penalaran model ketiga ini, tentu dengan berbagai modifikasi di sana-sini. Penggunaan kedua epistemologi tersebut pada hukum Islam, sebagaimana terlihat dari contoh-contoh yang diberikan oleh penganjurnya (poligami oleh Fazlur Rahman dan pembagian warisan bagi anak lakilaki dan perempuan oleh Munawir Sjadzali), menunjukkan dinamika yang menarik dari proses itu. Perubahan terhadap fikih klasik terjadi secara radikal sehingga fikih dapat 
menyesuaikan dirinya dengan perubahan zaman yang menuntut adanya kesetaraan antara laki-laki dengan perempuan. Dengan perubahan inilah hukum Islam dapat dianggap sesuai dengan zamannya.

Namun perubahan radikal yang dihasilkan pembaharuan yang menekankan pada tafsir kontekstual dan asas maslạ̣ah menyisakan ruang persoalan yang jika tidak segera ditangani dapat mendorong ke arah pembaharuan yang liberal dan terjebak dalam lubang relativitas kebenaran sehingga membahayakan otentisitas agama (Islam). Hal ini tampak, misalnya, pada aplikasi penekanan asas maslaḥah yang digunakan Sjadzali dalam pembagian warisan anak laki-laki dan perempuan di mana masing-masing mendapat bagian sama rata 1:1 (Nafis, 1995: 92).

Gagasan ini tentu saja berseberangan dengan bunyi nas qat'i QS al-Baqarah ayat 173 yang secara tegas dan jelas menyebutkan bagian anak laki-laki dua kali bagian anak perempuan. Di titik inilah, asas maslaḥah menyimpan potensi besar disalahgunakan untuk menjustifikasi berbagai persoalan yang bertentangan dengan nas yang sarị̣. Seseorang akan dengan mudah mengatasnamakan "kemaslahatan” untuk melakukan hal-hal yang bertentangan dengan syariat. Pun demikian, atas nama "kemaslahatan" seseorang akan dengan mudah menganggap suatu doktrin yang telah qat’i sebagai tidak berlaku dan harus dilakukan ijtihad. Maka, penggunaan asas maslaḥah perlu diperjelas dengan kriteria-kriteria tertentu yang bisa memperjelas sosok "kemaslahatan" itu. Kemaslahatan yang bagaimanakah yang bisa digunakan sebagai dasar pengambilan keputusan yang syar'i itu. Tanpa kejelasan itu, maslahab justru akan dimanfaatkan sebagai pembenar bagi tindakan-tindakan yang salah dan pembatal doktrin-doktrin yang qat'i.

Sesungguhnya persoalan penentuan mașlaḥah sudah muncul sejak lama. Dalam hal ini Ibrahim Hosen (Hosen, 1995: 259-260) memberikan contoh yang menarik tentang hadis: "tidak memadlaratkan dan tidak dimadlaratkan", di mana terdapat pendapat yang berbedabeda dalam aplikasinya, sebagai berikut:

1) Masalah mendirikan bangunan di atas tanah milik orang lain tanpa izin. Sebagian ulama berpendapat, pemilik tanah berhak membongkar bangunan tersebut tanpa harus mengganti kerugian atas dasar di atas. Sebagian ulama lain berpendapat, pemilik bangunan berhak memiliki tanah yang ada bangunannya tersebut dengan cara membayar harga 
tanah kepada pemiliknya. Sedangkan pemilik tanah berhak khiyär: mengganti harga bangunan itu jika hendak dibongkarnya atau menjual tanahnya kepada pemilik bangunan.

2) Seseorang merampas suatu benda. Menurut hukum qat'i benda itu wajib dikembalikan kepada pemiliknya dan jika hilang wajib diganti. Yang jadi persoalan, berapakah ia wajib mengganti benda yang dirampasnya itu? Sebagian ulama berpendapat ia wajib menggantinya dengan harga pasar pada hari terjadinya perampasan. Sebagian yang lain berpendapat sesuai harga pasar saat ia menggantinya. Sebagian lagi berpendapat sesuai dengan harga tertinggi di antara dua harga tersebut.

Menurut Hosen, perbedaan dalam menentukan maslạ̣ah terjadi pada aspek rasa maslahah yang berbeda-beda antara individu. Nilai mașlạ̣ah memang universal dan sama, namun rasa maslahah yang tidak sama dan tergantung pada masing-masing orang. Padahal, pencapaian nilai mașlạ̣ah tidak akan terjadi tanpa terlebih dahulu melalui tangga rasa maslạ̣ah itu. Lebih dari itu, praktik pengutamaan asas maslạ̣ah daripada hukum yang dibangun atas nas yang qat’i sebagaimana yang dilakukan Sjadzali dalam hal warisan anak laki-laki dan perempuan di atas seolah-olah menyatakan bahwa nas yang qat'i tersebut sudah tidak lagi mengandungi kemaslahatan, atau kemaslahatan di dalamnya sudah tidak ada lagi, sehingga perlu diganti dengan hukum baru yang mengandungi kemaslahatan.

Bukan hanya persoalan mașlạ̣ah yang perlu penjelasan lebih rinci untuk menutup pintu kesemena-menaan dalam penggunaannya, epistemologi tafsir kontekstual juga perlu diperjelas agar tidak terjatuh ke dalam lubang kesalahan yang sama sebagaimana asas mașlạ̧ah di atas. Di titik ini kita perlu mengajukan pertanyaan, seberapa besarkah peran kondisi sosio-historis dalam mempengaruhi pembentukan hukum Islam di masa lalu? Jika memang konteks itu sangat berpengaruh, lalu dimana letak peran ajaran Islam sebagai kekuatan transformatif? Pertanyaan-pertanyaan ini perlu segera dijawab untuk memperjelas pengaruh aspek historis dalam ajaran-ajaran Islam agar tampak dengan jelas posisi ajaran Islam, apakah sekedar berposisi sebagai pemberi justifikasi bagi realitas sosial atau justru menjadi pembaharu yang merubah realitas itu.

Tidak bisa dipungkiri produk pemikiran manusia pasti tidak lepas dari konteks kesejarahannya. Namun dalam membaca konteks historis itu diperlukan secara sikap obyektif dan ketelitian agar dapat melihat konteks itu secara jernih sebagaimana adanya. Sayangnya, 
hal itu kurang tampak dalam kasus poligami. Dalam kasus pernikahan poligami yang dijadikan contoh Fazlur Rahman misalnya, kesimpulan bahwa Islam berupaya menghapus pernikahan poligami secara bertahap dan menggiring umat kepada pernikahan monogami sesungguhnya merupakan kesimpulan yang lahir dari pembacaan parsial atas konteks sosio-historis Arab abad VII.

Selain praktik poligami, ternyata masyarakat Arab pagan pra-Islam juga mempraktikkan perkawinan zawajj al-aqat, dimana seorang anak laki-laki akan mengawini istri ayahnya (ibunya) yang meninggal dunia sebagai harta warisan dan perkawinan mut'ah (sementara) (Nasir, 2009: 21-22). Perkawinan lain yang juga berlaku di saat itu adalah:

Pertama, model perkawinan seperti yang berlaku saat ini dimana seorang lelaki meminta kepada seorang laki-laki untuk melamar seseorang wanita yang berada di bawah perlindungannya atau saudara perempuannya untuk dinikahi dengan memberikan sejumlah mahar.

Kedua, Seorang suami mengirim is trinya kepada seseorang yang terpandang untuk ditiduri selama beberapa waktu, ketika ada tanda-tanda hamil suami tersebut menjemput kembali istrinya. Ini dilakukan agar keluarga tersebut bisa mempunyai keturunan yang mulia. Pernikahan model ini disebut istibdāl.

Ketiga, sekelompok laki-laki kurang dari 10 orang dalam waktu bersamaan kawin dengan seorang wanita dan secara bergantian tidur dengan perempuan itu. Jika wanita itu hamil dan melahirkan seorang anak, maka dia akan membawa anak itu kepada suami-suaminya. Kemudian ia menunjuk sesuai seleranya salah satu diantara suaminya itu yang berhak menjadi ayah bagi anaknya. Para lelaki yang menjadi suami itu tidak punyak hak untuk menolak keputusan si istri tersebut.

Keempat, para lelaki mendatangi seorang gadis untuk melakukan hubungan seksual dan gadis itu tidak bisa menolaknya. Biasanya gadis yang berkeinginan melakukan itu memasang bendera di pintu rumahnya sebagai tanda. Saat dia hamil dan melahirkan, maka dia menemui para lelaki itu dan mengundang seorang dukun (aqif) untuk menentukan siapa bapak dari anaknya.

Dari berbagai praktik perkawinan yang menjadi tradisi masyarakat Arab jahiliyah itu, sebagian besar ditolak oleh Islam. Ada pula yang tetap dilestarikan dengan beberapa modifikasi di dalamnya. Praktik perkawinan seorang wanita dengan banyak suami (poliandri) seperti 
pada model ketiga dan keempat diatas jelas-jelas dilarang oleh Islam. Begitu juga dengan perkawinan model kedua dan perkawinan dimana seorang anak laki-laki menikahi istri ayahnya sebagai harta waris juga telah dihapuskan oleh Islam. Sedangkan perkawinan poligami dimana seorang lelaki memiliki beberapa istri dalam waktu bersamaan dan pernikahan model pertama diatas tetap diberlakukan Islam dengan penyempurnaan dalam praktik pelaksanaannya.

Jika dalam masa jahiliyah poligami dilakukan tanpa batasan jumlah istri, Islam memperbaikinya dengan memberi batasan jumlah istri maksimal empat menurut jumhur ulama', delapan menurut Mazhab Zahiri, atau sembilan belas menurut Khawarij dan sebagian Syiah. Pun demikian izin kebolehan poligami itu disertai dengan syarat perlakuan "adil" suami kepada istri-istrinya. Dalam pernikahan model pertama, seorang lelaki menikahi seorang wanita dengan memberikan mahar, Islam juga melestarikannya dengan perbaikan, yaitu pemberian mahar diberikan kepada wanita yang akan dinikahinya, bukan kepada orangtua/ wali wanita sebagaimana yang berlaku dalam pernikahan model itu di masa jahiliyah (Lihat juga Karim, 2009: 52).

Dengan demikian, kebolehan poligami dengan batasan dan persyaratan itu bukanlah strategi Islam untuk menghapus secara gradual praktik pernikahan seorang lelaki dengan beberapa istri sehingga di suatu saat praktik itu hilang sama sekali. Yang terjadi sesungguhnya adalah Islam berupaya menyeleksi praktik-praktik tradisi perkawinan yang berlaku di masa jahiliyah. Model perkawinan ala jahiliyah yang dianggap tidak sesuai dengan spirit ajaran Islam dihapus oleh Islam, sedangkan yang tidak bertentangan dilestarikan dan disempurnakan agar benar-benar sesuai dengan ajaran Islam.

Jika memang Islam berupaya secara gradual menghapus praktik poligami dengan alasan ketidaksiapan masyarakat saat itu, mengapa Islam tidak melakukan hal serupa saat menghapuskan praktik perkawinan lainnya yang juga populer di masyarakat Arab jahili seperti perkawinan model kedua, ketiga dan keempat di atas, atau perkawinan seorang anak dengan ibunya sendiri setelah sang ayah meninggal.

Tentang patriarkisme yang dianggap sebagai sebab maraknya poligami di masyarakat Arab abad VII, praktik perkawinan poliandri seperti model ketiga dan keempat diatas memberikan isyarat bahwa patriarkisme tidak sepenuhnya tepat. Hal ini diperkuat oleh fakta sejarah bahwa banyak suku-suku di Arab yang memposisikan wanita secara terhormat. 
Suku Ummu Aufah, Kindah, dan beberapa suku yang tinggal di Mekkah, Madinah, Yaman dan sekitarnya ternyata dipimpinan oleh wanita. Praktik penguburan hidup anak-anak wanita juga tidak dilakukan semua suku di Arab. Tradisi itu hanya berlaku di beberapa suku seperti Bani Tamim dan Bani Asad dengan alasan ekonomi dan dianggap membawa aib (Karim, 2009: 51).

\section{Penutup}

Pembaharuan hukum Islam merupakan sesuatu yang mesti dilakukan untuk menjaga eksistensi ajaran Islam sebagai universal. Namun pembaharuan yang dilakukan hendaklah memperhatikan Islam sebagai ajaran yang qat'i dan kekal dari Allah Swt. Pembaharuan yang semena-mena dan serampangan justru dapat menjauhkannya dari tujuan semula itu. Bahkan pembaharuan yang seperti itu dapat menggerogoti sendi-sendi ajaran Islam sehingga berpotensi merobohkan bangunan agama itu sendiri.

Dalam hal ini, para ulama' klasik telah memberikan formulasi dan kaidah-kaidah yang mapan untuk menyediakan seperangkat metodologi yang dapat digunakan untuk berijtihad menghasilkan hukum-hukum fikih baru yang up to date tanpa harus mengorbankan sendisendi agama. Kaidah-kaidah itu telah dibakukan dalam bentuk Usūul fiqh dan qawaid fiqh. Kiranya, metodologi yang terkandung di dalamnya hingga kini masih layak untuk dijadikan pegangan dalam melakukan pembaharuan hukum Islam kontemporer.

\section{Daftar Pustaka}

Amal, Taufik Adnan. Islam dan Tantangan Modernitas; Studi Atas Pemikiran Hukum Fazlur Rahman. Bandung: Mizan, 1996.

Asni. Pembaharuan Hukum Islam di Indonesia; Telaab Epistemologis Kedudukan Perempuan dalam Hukum Keluarga. Jakarta: Dirjen Pendis Kemenag RI., 2012.

Boy ZTF, Pradana. "Fatwa in Islamic Legal Theory", dalam Jurnal Maqasid, vol 1, no 1, June 2012, 1-20.

Hosen, Ibrahim. "Beberapa Catatan tentang Reaktualisasi Hukum Islam”, dalam Muhammad Wahyuni Nafis dkk (ed). Reaktualisasi Hukum Islam: 70 Tabun Prof DrMunawir Sjadzali, MA. Jakarta: Paramadina \& IPHI, 1995.

Karim, M Abdul. Sejarah Pemikiran dan Peradaban Islam. Yogyakarta: Pustaka Book Publisher, 2009. 
ljtihad, Jurnal Wacana Hukum Islam dan Kemanusiaan, Volume 13, No. 2, Desember 2013: 163-178

Lubis, Nur A Fadhil. "Islamic Legal Studies in Indonesia: Some Notes on Contemporary Challenges", dalam Prosiding AICIS (Annual International Conference on Islamic Studies), diselenggarakan oleh Kementerian Agama RI dengan IAIN Sunan Ampel, 5-7 November 2012, 1-12.

Muzammil, Iffah. "Evolusi Syariab: Studi Pembaharuan Hukum Islam Menurut Mahmud Mubammad Thaha", dalam Prosiding AICIS (Annual International Conference on Islamic Studies), diselenggarakan oleh Kementerian Agama RI dengan IAIN Sunan Ampel, Surabaya, di Hotel Empire Palace Surabaya, 5-7 November 2012, 332-353.

Nafis, Muhammad Wahyuni, dkk (ed). 1995. Kontekstualisasi Ajaran Islam; 70 Tabun Prof Dr H Munawir Sjadzali, MA. Jakarta: Paramadina \& IPHI.

Nasir, Jamal J Ahmad. The Status of Women under Islamic Law and Modern Islamic Legislation. Leiden \& London: Brill's Arab \& Islamic Law Series, 2009.

Zein, Satria Effendi. "Munawir Sjadzali dan Reaktualisasi Hukum Islam di Indonesia," dalam Muhammad Wahyuni Nafis, dkk (ed). Kontekstualisasi Ajaran Islam: 70 Tabun Prof Dr H Munawir Sjadżali. Jakarta: Paramadina \& IPHI, 1995. 